\title{
Maternal nest building by pseudopregnant mice
}

\author{
R. Gandelman, N. J. McDermott, M. Kleinman and Denise DeJianne
}

Department of Psychology, Rutgers University, New Brunswick, New Jersey 08903, U.S.A.

Summary. Pseudopregnant mice displayed maternal nest-building behaviour. Their nests were smaller but qualitatively identical to those constructed by pregnant animals.

\section{Introduction}

The nest building performance of pregnant mice clearly shows the influence of gonadal hormones upon behaviour. Commencing on about the 4th day post coitum mice construct from available material nests within which the young are raised (Koller, 1956). These 'maternal nests', unlike the small saucer-shaped 'sleeping nests', are large enclosed bowl-shaped structures having a number of entrance/exit tunnels. The construction of the maternal nest, which ceases a day or two before parturition, has been shown to be promoted by gonadal hormones. Koller (1952) demonstrated that maternal nest building can be elicited from non-pregnant, gonadally intact, mice by daily injections of progesterone. This finding has since been confirmed by others (Lisk, 1971; Zarrow, Gandelman \& Denenberg, 1971; Gandelman, 1973). In addition, Voci \& Carlson (1970) reported an increase in nest building following placement of minute amounts of progesterone into the hypothalamus.

Maternal nest building apparently results from the synergism between progesterone and oestrogen since little nest building is displayed by ovariectomized mice treated with progesterone only. Such animals, however, will construct the maternal nest as a consequence of progesterone/oestrogen administration providing that the oestrogen dose is small (Lisk, 1971). These reports are congruent with what is known about ovarian hormones during pregnancy. Progesterone levels are markedly elevated from about the 3rd day of gestation and decline on Day 17 (Murr, Stabenfeldt, Bradford \& Geshwind, 1974; Virgo \& Bellward, 1974). In contrast, oestrogen levels, relatively low during most of the gestation period, rise a day or two before parturition (Shaikh, 1971). Therefore, the decline in nest building during the last part of pregnancy probably results from the rising titres of oestrogen since the administration of relatively large doses of oestrogen inhibits progesterone-induced nest building (Lisk, 1971).

Although the elicitation of nest-building behaviour can be attributed to gonadal hormones, especially to progesterone, little if anything is known about the nest-building behaviour of mice subjected to certain naturally occurring events which markedly affect reproductive status. One such event is pseudopregnancy.

Pseudopregnancy, a condition which yields hormonal changes similar to those occurring during pregnancy, undoubtedly occurs in the natural environment following, for example, copulation with a sterile male. The following experiment attempted to determine whether pseudopregnant animals construct maternal nests.

\section{Materials and Methods}

The animals were Rockland-Swiss albino mice that had been maintained as an outbred strain in a closed colony. They were kept in $28 \times 18 \times 13 \mathrm{~cm}$ plastic cages and provided with food and water in excess. A 12-h light:12-h dark cycle was imposed with lights on at 06:00 h. Data collection commenced at 09:00 h. 
At 60 days of age virgin females were assigned to 1 of 3 groups. Group 1 consisted of timedmated animals and were considered to be pregnant. Group 2 females were housed with testosterone-treated castrated males and were therefore pseudopregnant. Females in Group 3 were left undisturbed as virgins. Each group contained 12 animals. Each animal in Groups 1 and 2 was housed individually and provided with nesting material within 30 min of the discovery of a copulatory plug. The virgin females, also housed individually, were provided with nesting material at the same time as were the pseudopregnant and pregnant animals. A pre-weighed $30-40 \mathrm{~g}$ ball of absorbant cotton was placed into a receptacle on top of the cage. On the following morning, the cotton pulled by the mouse into the cage was removed and discarded. The material remaining in the receptacle was weighed and replenished. When this procedure was used previously, it was found that practically all of the cotton pulled into the cage was incorporated into a nest (Zarrow et al., 1971; Gandelman, 1973). The amount of cotton pulled into the cage is therefore a reliable indicator of nest size and the amount of nest building.

Vaginal smears were taken immediately after weighing the nesting material to verify that the animals in Group 2 were pseudopregnant. Vaginal smears were also taken from the mice in Group 3 to control for any effects of handling and smearing procedures.

Nest building data were collected for 10 days from the time of mating in Groups 1 and 2 . Previous data have shown that the minimum duration of pseudopregnancy for these mice is 10 days.

\section{Results}

The vaginal smears revealed that all of the mice in Group 2 were in dioestrus throughout the 10 days of testing.

The average amount of cotton pulled into the cage each day by the 3 groups of mice is shown in Text-fig. 1. An overall analysis of variance showed that there was a statistically significant group effect $(f=18.68$, d.f. $=2 / 3, P<0.001)$. In addition, there was a significant change in nest building during the 10 -day test period $(f=10.98$, d.f. $=9 / 29, P<0.001)$ and a significant 'group $\times$ day' interaction $(f=4.32$, d.f. $=18 / 297, P<0.001)$. A between-groups comparison using Duncan's Test $(\alpha=0.05)$ showed that the pseudopregnant animals pulled more cotton into their cages than did the virgin controls while the pregnant mice pulled more nesting material than did the pseudopregnant animals. These data show that pseudopregnancy is a sufficient condition for the elicitation of maternal nest building behaviour.

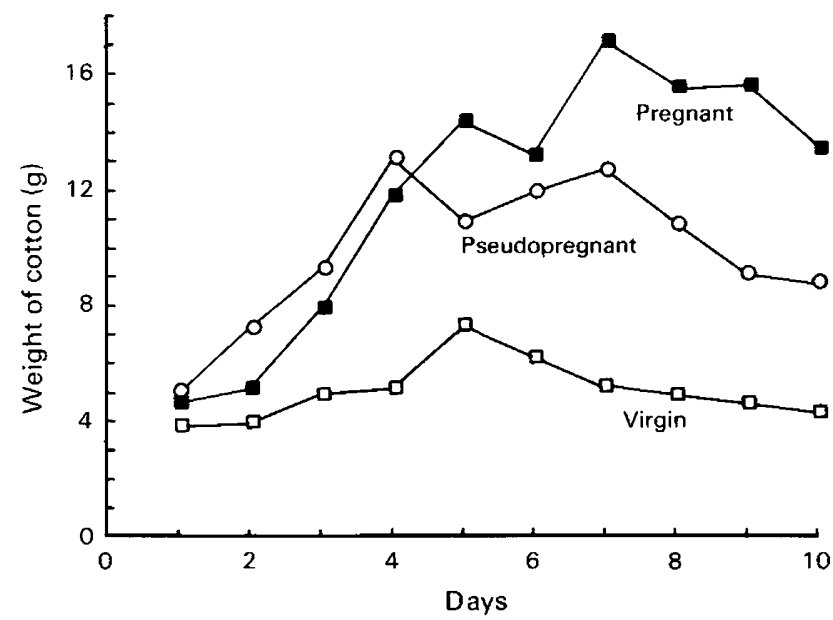

Text-fig. 1. The average amount of cotton pulled per day for nest building by pregnant $(\mathrm{N}=12)$ and pseudopregnant $(\mathrm{N}=12)$ mice. Virgin females $(\mathrm{N}=12)$ were tested in a random 10-day period. 


\section{Discussion}

The results of this study have shown that maternal nest building can be elicited by pseudopregnancy. Pseudopregnant animals displayed a significant increase in nest building compared with that of virgin females but the nests built were smaller than those of the pregnant animals, although qualitatively identical.

The relationship between nest building and pseudopregnancy is congruent with what is known about the endocrine events surrounding pseudopregnancy. DeGreef \& Zeilmaker (1974) and DeGreef, Dullart \& Zeilmaker (1976) reported a significant rise in plasma progesterone concentration in the rat commencing soon after the induction of pseudopregnancy and reaching a plateau on Day 4-5. The present experiment shows that the increase in the pulling of nesting material began about Day 3 after the sterile mating, strongly suggesting that the rising titres of progesterone are responsible for the initiation of maternal nest building.

The fact that the pregnant mice constructed larger maternal nests than did the pseudopregnant animals may be due to declining levels of progesterone in the pseudopregnant animals which, for the rat, occurs on Day 9 (Pepe \& Rothchild, 1974). This decline may occur earlier for the mouse. It also is possible that no difference in the amount of nest building would have been observed had decidual tissue been present in the pseudopregnant animals. Rothchild \& Gibori (1975) reported higher levels of progesterone in deciduoma-bearing than in nondeciduoma-bearing pseudopregnant rats.

In summary, the data have shown that pseudopregnancy not only results in endocrine changes but also alters behaviour. Whether this behavioural effect influences population regulation in the mouse remains to be determined.

The research was supported by Grant MH-28660 from NIH, by Grant BNS-07347 from NSF, and by a grant from the Charles and Johanna Busch Memorial Fund.

\section{References}

DeGreef, W.J. \& Zeilmaker, G.H. (1974) Blood progesterone levels in pseudopregnant rats: effects of partial removal of luteal tissue. Endocrinology 95, $565-571$.

DeGreef, W.J., Dullart, J. \& Zeilmaker, G.H. (1976) Effect of hysterectomy on serum lutenizing hormone concentrations and on corpus luteum function in the rat. Endocrinology 98, 1228-1234.

Gandelman, R. (1973) Reduction of maternal nest building in female mice by testosterone propionate treatment. Devel. Psychobiol. 6, 539-546.

Koller, G. (1952) Der Nestbau der weissen Maus und seine hormonale Auslosung. Zool. Anz., Suppl. 17, 160-168.

Koller, G. (1956) Hormonale und psychische Steuerung beim Nestbau weiser Mause. Zool. Anz., Suppl. 19, 123-132.

Lisk, R.D. (1971) Oestrogen and progesterone synergism and elicitation of maternal nest-building in the mouse (Mus musculus). Anim. Behav. 19, 606-610.

Murr, S.M., Stabenfeldt, G.H., Bradford, G.E. \& Geshwind, I.I. (1974) Plasma progesterone during pregnancy in the mouse. Endocrinology 94, 12091211 .
Pepe, G.J. \& Rothchild, I. (1974) A comparative study of serum progesterone levels in pregnancy and in various types of pseudopregnancy in the rat. Endocrinology 95, 275-279.

Rothchild, 1. \& Gibori, G. (1975) The luteotrophic action of decidual tissue: the stimulating effect of decidualization on the serum progesterone level of pseudopregnant rats. Endocrinology 97, 838842 .

Shaikh, A.A. (1971) Estrone and estradiol levels in the ovarian venous blood from rats during the estrous cycle and pregnancy. Biol. Reprod. 5, 297-307.

Virgo, B.B. \& Bellward, G.D. (1974) Serum progesterone levels in the pregnant and postpartum laboratory mouse. Endocrinology 95, 1486-1490.

Voci, V.E. \& Carlson, N.R. (1970) Enhancement of maternal behavior and nest building following systemic and diencephalic administration of prolactin and progesterone in the mouse. J. comp. Physiol. Psychol. 83, 388-393.

Zarrow, M.X., Gandelman, R. \& Denenberg, V.H. (1971) Lack of nest building and maternal behavior in the mouse following olfactory bulb removal. Horm. \& Behav. 2, 227-238. 